\title{
Analisis Kualitas Pelayanan Kartu Tanda Penduduk Di Kantor Kecamatan Samarinda Seberang Kota Samarinda Provinsi Kalimantan Timur
}

\author{
Shorea Helminasari \\ E-mail: \\ Dosen Ilmu Administrasi Negara FISIP UWGM Samarinda
}

\begin{abstract}
Abstrak
Pelayanan merupakan tugas utama yang hakiki dari sosok aparatur, sebagai abdi negara dan abdi masyarakat. Salah satu bentuk pelayanan pubik yang dilakukan oleh pemerintah daerah khususnya di Kantor Kecamatan adalah pelayanan administrasi kependudukan khususnya pelayanan Kartu Tanda Penduduk (KTP). Namun selama ini masyarakat banyak merasakan ketidakpuasan dengan pelayanan yang diberikan oleh pemerintah.

Tujuan penelitian ini adalah untuk mengetahui dan mengindentikasi faktor yang mempengaruhi kualitas pelayanan publik di Kantor Kecamatan Samarinda Seberang khususnya berkaitan dengan pelayanan KTP.Menggunakan pendekatan kualitatif. Pengumpulan data dilakukan dengan cara observasi dan wawancara langsung dengan informan di lokasi penelitian. Dari tahapan ini, dilakukan analisis data kualitiatif menggunakan metode data model interaktif.

Hasil penelitian ini adalah: 1)Kualitas pelayanan publik di Kantor Kecamatan Samarinda Seberang dapat dikatakan masih rendah 2) Kemampuan aparat, iklim organisasi dan sistem pelayanan tidak mendukung kualitas pelayanan KTP.Untuk itu disarankan agar 1) peningkatan kemampuan aparatur dari segi kualitas dan kuantitas 2) perlu ditingkatkan koordinasi antar instansi 3) peningkatan ruang akses informasi bagi masyarakat.
\end{abstract}

Kata kunci: pelayanan, KTP, Kota Samarinda

\section{Abstract}

\section{Pendahuluan}

Sebagaimana termuat dalam Undang-undang Nomor 32 Tahun 2004 tentang Pemerintahan Daerah, tujuan kebijakan otonomi daerah adalah mempercepat terwujudnya kesejahteraan masyarakat melalui peningkatan pelayanan, pemberdayaan, dan peran serta masyarakat serta peningkatan daya saing daerah dengan memperhatikan prinsip pemerataan, keadilan, keistimewaan dan kekhususan daerah dalam rangka menjaga keutuhan Negara Kesatuan Republik Indonesia.

Pelayanan merupakan tugas utama yang hakiki dari sosok aparatur, sebagai abdi negara dan abdi masyarakat. Tugas ini telah jelas digariskan dalam Pembukaan UUD 1945 alenia keempat, yang meliputi 4 (empat) aspek pelayanan pokok aparatur terhadap masyarakat, yaitu melindungi segenap bangsa Indonesia dan seluruh tumpah darah Indonesia, memajukan kesejahteraan umum, mencerdaskan kehidupan bangsa dan melaksanakan ketertiban dunia yang berdasarkan kemerdekaan, perdamaian abadi dan keadilan sosial.

Ruang lingkup pelayanan publik (public services) meliputi aspek kehidupan masyarakat yang sangat luas. Pelayanan publik bahkan dimulai sejak seseorang dalam kandungan ketika diperiksa oleh dokter pemerintah atau dokter yang dididik di universitas negeri, mengurus akta kelahiran, menempuh pendidikan di universitas negeri, menikmati bahan makanan yang pasarnya dikelola oleh pemerintah, menempati rumah yang disubsidi pemerintah, memperoleh macam-macam perijinan yang berkaitan 
dengan dunia usaha yang digelutinya hingga seseorang meninggal dan memerlukan surat pengantar dan surat kematian untuk mendapatkan kapling di tempat pemakaman umum.

Namun selama ini masyarakat banyak merasakan ketidakpuasan dengan pelayanan yang diberikan oleh pemerintah dengan persepsi "birokrasi yang berbelit-belit". Birokrasi dianggap lebih dinilai sebagai "penguasa" dibandingkan sebagai "abdi negara". Keinginan masyarakat untuk mendapatkan pelayanan yang prima dengan kualitas terbaik hanya sebagai angan-angan saja. Tidak ada implementasi pelayanan pubilk yang diterapkan secara nyata dalam penyelenggaraan sehari-hari pada setiap jenis pelayanan yang diberikan oleh pemerintah. Padahal Handayaningrat (1983), mengungkapkan kelancaran penyelenggaraan pemerintahan sangat bergantung pada kesempurnaan aparatur dalam melaksanakan tugasnya terhadap publik/masyarakat.

Salah satu bentuk pelayanan pubik yang dilakukan oleh pemerintah daerah khususnya di Kantor Kecamatan Samarinda Seberang, Kota Samarinda, Provinsi Kalimantan Timur adalah pelayanan administrasi kependudukan khsusnya pelayanan Kartu Tanda Penduduk (KTP). Pelayanan ini didasarkan pada:

1. Peraturan Pemerintah Nomor 19 Tahun 2008 tentang Kecamatan

2. Peraturan Walikota Samarinda Nomor 13 Tahun 2008 tentang Organisasi dan Tata Kerja Kecamatan Kota Samarinda

3. Peraturan Walikota Samarinda Nomor 31 Tahun 2006 tentang Pembebasan Biaya Pembuatan Kutipan Akta Kelahiran, Kartu Keluarga dan Kartu Tanda Penduduk untuk Masyarakat dalam Wilayah Kota Samarinda

Namun, dalam perjalanannya masih banyak dijumpai permasalahan yang berkaitan dengan pemberian pelayanan kepada masyarakat. Telah banyak cerita atau pengalaman dari sebagian atau bahkan hampir semua masyarakat sebagai pengguna dari pelayanan publik yang mengeluhkan terhadap pelayanan yang telah diberikan oleh Kantor Kecamatan Samarinda Seberang tersebut.

Melalui observasi awal (2 Oktober 2009) yang telah dilakukan, berikut ini disajikan fenomena yang diperoleh melalui web site Pemerintah Kota Samarinda dan wawancara langsung dengan masyarakat tentang pelayanan publik khsusnya yang berkaitan dengan pelayanan Kartu Tanda Penduduk (KTP) sebagai berikut:

1. Sekkot Samarinda HM Fadly Illa SH MS dalam Rakor Kependudukan mengakui bahwa pelayanan publik di Kota Samarinda harus ditingkatkan khususnya pelayanan administrasi kependudukan. (www.samarinda.co.id, diakses tanggal 2 Oktober 2009)

2. "Buat KTP memang prosudernya mudah, tapi petugasnya tidak ada yang ramah. Kalau kita nggak perlu, mungkin saya nggak buat KTP” (Andi Baskoro, wawancara, 2 Oktober 2009)

3. "Buat KTP gratis, tapi waktunya lama. Saya tidak tahu pastinya kapan selesainya. Katanya seminggu, setelah seminggu eh belum selesai juga. Di suruh datang lagi minggu depan" (Asnah, wawancara, 2 Oktober 2009)

Fenomena diatas mengindiasikan masih buruknya kualitas pelayanan publik yang selama ini dinikmati oleh masyarakat. Sudah sejak lama masyarakat mengeluh terhadap penyelenggaraan pelayanan publik yang dirasakannya amat jauh dari harapannya. Meskipun ada perbaikan, namun hal ini belum dinilai mampu memberikan pelayanan publik yang berkualitas khsusnya dalam pelayanan Kartu Tanda Penduduk (KTP).

\subsection{Rumusan masalah}

Permasalahan yang diangkat pada penelitian ini yakni mengenai kualitas dan faktor-faktor yang mempengaruhi pelayanan publik di Kantor Kecamatan Samarinda Seberang khususnya berkaitan dengan pelayanan KTP ditinjau dari ketepatan waktu, kemudahan prosedur, akurasi dan biaya sudah berkualitas serta kemampuan aparat, iklim organisasi dan sistem dan prosedur pelayanan. 


\subsection{Tujuan}

Berdasarkan perumusan masalah tersebut seperti yang telah diuraikan diatas, penulis dalam mengadakan penelitian tersebut memiliki tujuan untukMengetahui,mengidentifikasi faktor-faktor dan merumuskan langkah-langkah dan memberikan rekomendasi dalam meningkatkankualitas pelayanan publik di Kantor Kecamatan Samarinda Seberang khususnya berkaitan dengan pelayanan KTP.

\section{Kerangka teori}

\subsection{Pelayanan Publik}

Pengertian pelayanan pubik telah dikemukakan banyak ahli. Menurut Syahrir (1987), pelayanan publik adalah segala aktivitas yang dilakukan oleh pemerintah maupun swasta yang menghasilkan barang dan jasa, yang ditujukan untuk memenuhi kebutuhan publik. Hal senada juga diungkapkan Lembaga Administrasi Negara (2003) pelayanan publik sebagai segala bentuk kegiatan pelayanan umum yang dilaksanakan oleh Instansi Pemerintah di Pusat, di Daerah dan di lingkungan Badan Usaha Milik Negara/Daerah dalam bentuk barang dan atau jasa baik dalam rangka upaya kebutuhan masyarakat maupun dalam rangka pelaksanaan ketentuan peraturan perundang-undangan.

Sedangkan berdasarkan Keputusan Menteri Pendayagunaan Aparatur Negara Nomor 81 Tahun 1993 Tentang Pedoman Tatalaksana Pelayanan Umum, disebutkan pengertian pelayanan umum sebagai segala bentuk kegiatan pelayanan umum yang dilaksanakan oleh instansi pemerintah di pusat maupun di daerah dan di lingkungan BUMN/BUMD, dalam bentuk barang/jasa, baik dalam rangka upaya pemenuhan kebutuhan masyarakat maupun dalam rangka pelaksanaan ketentuan peraturan perundang-undangan (Moenir, 1992).

Dalam konsep pelayanan, dikenal dua jenis pelaku pelayanan, yaitu penyedia layanan dan penerima layanan. Penyedia layanan atau service provider (Barata, 2003) adalah pihak yang dapat memberikan suatu layanan tertentu kepada konsumen, baik berupa layanan dalam bentuk penyediaan da penyerahan barang (goods) atau jasa-jasa (services). Penerima layanan atau service receiver adalah pelanggan (customer) atau konsumen (consumer) yang menerima layanan dari para penyedia layanan.

Sementara karakteristik khusus dari pelayanan publik yang membedakannya dari pelayanan swasta adalah:

1) Sebagian besar layanan pemerintah berupa jasa, dan barang tak nyata. Misalnyaperijinan, sertifikat, peraturan, informasi keamanan, ketertiban, kebersihan, transportasi dan lain sebagainya.

2) Selalu terkait dengan jenis pelayanan-pelayanan yang lain, dan membentuk sebuah jalinan sistem pelayanan yang bersaka regional, atau bahkan nasional. Contonya dalam hal pelayanan transportasi, pelayanan bis kota akan bergabung dengan pelayanan mikrolet, bajaj, ojek, taksi dan kereta api untuk membentuk sistem pelayanan angkutan umum di Jakarta.

3) Pelanggan internal cukup menonjol, sebagai akibat dari tatanan organisasi pemerintah yang cenderung birokratis. Dalam dunia pelayanan berlaku prinsip utamakan pelanggan eksternal lebih dari pelanggan internal. Namun situasi nyata dalam hal hubungan antar lembaga pemerintahan sering memojokkan petugas pelayanan agar mendahulukan pelanggan internal.

4) Efisiensi dan efektivitas pelayanan akan meningkat seiring dengan peningkatan mutu pelayanan. Semakin tinggi mutu pelayanan bagi masyarakat, maka semakin tinggi pula kepercayaan masyarakat kepada pemerintah. Dengan demikian akan semakin tinggi pula peran serta masyarakat dalam kegiatan pelayanan.

5) Masyarakat secara keseluruhan diperlakukan sebagai pelanggan tak langsung, yang sangat berpengaruh kepada upaya-upaya pengembangan pelayanan. Desakan untuk memperbaiki pelayanan oleh polisi bukan dilakukan oleh hanya pelanggan langsung (mereka yang pernah mengalami gangguan keamanan saja), akan tetapi juga oleh seluruh lapisan masyarakat.

6) Tujuan akhir dari pelayanan publik adalah terciptanya tatanan kehidupan masyarakat yang berdaya untuk mengurus persoalannya masing-masing. (Barata, 2003) 
Pelayanan publik dengan demikian dapat diartikan sebagai pemberian layanan (melayani) keperluan orang atau masyarakat yang mempunyai kepentingan pada organisasi itu sesuai dengan aturan pokok dan tata cara yang telah ditetapkan.

\subsection{Tuntutan masyarakat terhadap pelayanan publik}

Negara dan sistem pemerintahan menjadi tumpuan pelayanan warga negara dalam memperoleh jaminan atas hak-haknya, maka peningkatan kualitas pelayanan (quality of service) akan semakin penting. Sebab manajemen publik sejak tahun 1980-an telah berubah oleh fenomena intemasional, yang antara lain lahimya kompetisi tingkat global (global competitiveness) dalam sektor pelayanan (Silalahi, et all,1975 dalam Soesilo Zauhar, 2001).

Ditambah lagi kondisi masyarakat saat ini telah terjadi suatu perkembangan yang sangat dinamis, tingkat kehidupan masyarakat yang semakin baik, merupakan indikasi dari empowering yang dialami oleh masyarakat (Thoha, 1996). Hal ini berarti masyarakat semakin sadar akan apa yang menjadi hak dan kewajibannya sebagai warga negara dalam hidup bermasyarakat, berbangsa dan bernegara. Masyarakat semakin berani untuk mengajukan tuntutan, keinginan dan aspirasinya kepada pemerintah. Masyarakat semakin kritis dan semakin berani untuk melakukan kontrol terhadap apa yang dilakukan oleh pemerintahnya. Lovelock (1994) menyebutkan bahwa pelayanan yang baik membutuhkan instruktur pelayanan yang sangat baik pula. Hal yang paling penting adalah membuat setiap orang dalam organisasi pada kualitas.

Jadi pada prinsipnya setiap pelayanan umum, senantiasa harus selalu ditingkatkan kinerjanyanya sesuai dengan keinginan klien atau masyarakat pengguna jasa. Akan tetapi kenyataannya untuk mengadakan perbaikan terhadap kinerja pelayanan publik bukanlah sesuatu yang mudah. Banyaknya jenis pelayanan umum di negeri ini dengan macam-macam persoalan dan penyebab yang sangat bervariasi antara satu dengan yang lainnya, sehingga perlu dicari suatu metode yang mampu menjawab persoalan tadi, guna menentukan prioritas pemerintah. (Harry P. Hatry, 1989).

Berdasarkan uraian diatas maka dapat ditarik simpulan bahwa pelayanan publik harus selalu ditingkatkan kualitasnya sejalan dengan meningkatnya kesadaran masyarakat atas hak dan kewajibanya sebagai publik yang dilayani.

\subsection{Kualitas Pelayanan}

Pada perkembangannya sekarang konsep pelayanan publik mengacu pada layanan yang memuaskan pada masyarakat oleh organisasi publik yang dikenal dengan konsep pelayanan prima. Crosby, Lehtimen dan Wyckoff (dalam Lovelock, 1994) mendefinisikan kualitas pelayanan sebagai "penyesuaian terhadap perincian-perincian (conformance io specification) dimana kualitas ini dipandang sebagai derajat keunggulan yang ingin dicapai, dilakukannya kontrol tenis menerus dalam mencapai keunggulan tersebut dalam rangka memenuhi kebutuhan pengguna jasa."

Zeithaml, et al (1990) mengemukakan dalam mendukung hal tersebut, ada 10 (sepuluh) dimensi yang harus diperhatikan dalam melihat tolok ukur kualitas pelayanan publik, yaitu sebagai berikut :

1. Tangible, terdiri atas fasilitas fisik, peralatan, personil dan komunikasi;

2. Realiable, terdiri dari kemampuan unit pelayanan dalam menciptakan pelayanan yang dijanjikan dengan tepat;

3. Responsiveness, kemauan untuk membantu konsumen bertanggung jawab terhadap kualitas pelayanan yang diberikan;

4. Competence, tuntutan yang dimilikinya, pengetahuan dan ketrampilan yang baik oleh aparatur dalam memberikan pelayanan;

5. Courtesy, sikap atau perilaku ramah, bersahabat, tanggap terhadap keinginan konsumen serta mau melakukan kontak atau hubungan pribadi;

6. Credibility, sikap jujur dalam setiap upaya untuk menarik kepercayaan masyarakat; 
7. Security, jasa pelayanan yang diberikan harus bebas dari berbagai bahaya dan resiko;

8. Access, terdapat kemudahan untuk mengadakan kontak dan pendekatan;

9. Communication, kemauan pemberi pelayanan untuk mendengarkan suara, keinginan atau aspirasi pelanggan, sekaligus kesediaan untuk selalu menyampaikan informasi baru kepada masyarakat;

10. Understanding the customer, melakukan segala usaha untuk mengetahui kebutuhan pelanggan.

Sedangkan Keputusan Menteri Pemberdayaan Aparatur Negara (Kep.Menpan) No.81 Tahun 1993 menyebutkan bahwa instrument dari pada layanan prima itu harus memenuhi sendi-sendi layanan, diantaranya :

1. Kesederhanaan, dalam arti bahwa prosedur/tata cara layanan diselenggarakan secara mudah, cepat, tidak berbelit-belit, mudah dipahami dan mudah dilaksanakan.

2. Kejelasan kepastian, dalam arti adanya kejelasan dan kepastian mengenai :

a. Prosedur/tata cara layanan umum;

b. Persyaratan layanan umum, baik teknis maupun administratif;

c. Unit kerja dan atau yang berwenang dan bertanggung jawab dalam memberikan layanan umum;

d. Rincian biaya/tarif layanan umum dan tata cara pembayarannya;

e. Jadwal waktu penyelesaian layanan umum;

f. Hak dan kewajiban, baik dari pemberi maupun penerima layanan umum, berdasarkan bukti-bukti penerimaan permohonan/kelengkapannya, sebagai alat untuk memastikan pemrosesan layanan umum;

g. Pejabat yang menerima keluhan masyarakat.

3. Keamanan, dalam arti bahwa proses serta hasil layanan publik dapat memberikan keamanan dan kenyamanan serta dapat memberikan kepastian hukum.

4. Keterbukaan, dalam arti prosedur/tata cara, persyaratan, satuan kerja/pejabat penanggung jawab pemberi pelayanan publik, waktu penyelesaian dan rincian biaya/tarif dan hal-hal lain yang berkaitan dengan proses layanan umum wajib diinformasikan secara terbuka agar mudah diketahui dan dipahami oleh masyarakat, baik diminta ataupun tidak diminta.

5. Efisien, dalam arti persyaratan pelayanan hanya dibatasi pada hal-hal yang berkaitan dengan maksud dan tujuan pelayanan yang diberikan, mencegah adanya pengulangan kelengkapan persyaratan, dalam hal proses layanannya mempersyaratkan kelengkapan sebagai persyaratan dari satuan kerja/instansi pemerintah lain yang terkait.

6. Ekonomis, dalam arti pengenaan biaya layanan publik harus ditetapkan secara wajar dengan memperhatikan nilai barang dan jasa layanan publik dan tidak menuntut biaya yang tinggi diluar kewajaran, kondisi dan kemampuan masyarakat untuk membayar secara umum, ketentuan peraturan perundang-undangan yang berlaku.

7. Keadilan yang merata, dalam arti cakupan/jangkauan piblik harus diusahakan selua mungkindengan distribusi yang merata dan diperlakukan secara adil.

8. Ketepatan waktu, dalam arti pelaksanaan layanan publik dapat diselesaikan dalam kurun waktu yang telah ditentukan.

Tulus (1992) mengungkapkan bahwa layanan yang didambakan adalah :

1. Adanya kemudahan dalam pengurusan kepentingan dengan layanan yang cepat dalam arti tanpa hambatan yang terkadang dibuat-buat. 
2. Layanan secara wajar, tanpa gerutu sendirian atau untaian kata lain semacam yang nadanya pada permintaan tertentu baik dengan alas an untuk dinas atau kesejahteraan.

3. Perlakuan yang sama dalam kepentingan yang sama, tertib dan tidak pandang bulu.

4. Pelayanan yang jujur dan terus terang, artinya apabila ada hambatan karena suatu masalah yang tidak dapat dielakkan hendaknya diberitahukan sehingga orang tidak menunggu sesuatu yang tidak menentu.

Pemerintah sebagai organisasi publik yang memberikan pelayanan kepada masyarakat menjadi dambaan masyarakat untuk dapatkan kualitas pelayanan yang maksimal. Jadi kualitas pelayanan publik adalah penyelenggaraan pelayanan publik yang diberikan oleh pemerintah yang dapat memuaskan masyarakat yang menerima pelayanan.

Berdasarkan uraian diatas juga dapat disimpulkan bahwa indikator-indikator dalam kualitas pelayanan publik adalah :

1. Ketepatan waktu pelayanan yang berkaitan dengan waktu tunggu dan proses

2. Kemudahan dalam pengajuan permohonan dan kelengkapan administrasi

3. Akurasi pelayanan yang berkaitan dengan apakah pelayanan tersebut bebas dari kesalahan

4. Besarnya biaya pelayanan

\subsection{Faktor Yang Mempengaruhi Kualitas Pelayanan Publik}

Organisasi pelayanan publik mempunyai ciri public accuntability, dimana setiap warga negara mempunyai hak untuk mengevaluasi kualitas pelayanan yang mereka terima. Adalah sangat sulit untuk menilai kualitas suatu pelayanan tanpa mempertimbangkan peran masyarakat sebagai penerima pelayanan dan aparat pelaksana pelayanan itu.

Evaluasi yang berasal dari pengguna pelayanan, merupakan elemen pertama dalam analisis kualitas pelayanan publik. Elemen kedua dalam analisis adalah kemudahan suatu pelayanan dikenali baik sebelum dalam proses atau setelah pelayanan itu diberikan.

Pada dasarnya ada 3 (tiga) ketentuan pokok dalam melihat tinggi rendahnya suatu kualitas pelayanan publik, yaitu sebagaimana gambar 2.1. berikut ini :

Gambar 2.1.Segitiga Keseimbangan dalam Kualitas Pelayanan(The Triangle of Balance in Service Quality)

(Inter Personal Component)

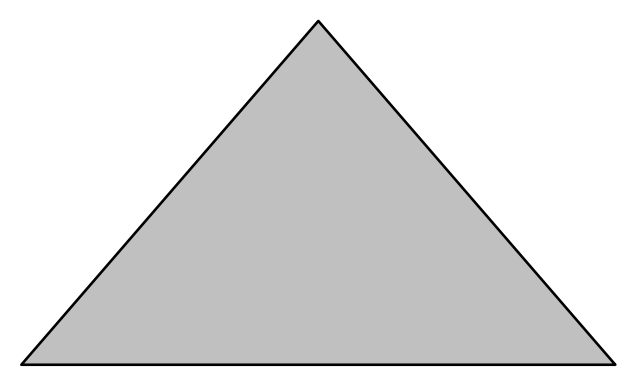

(Process/Environment Component) (Professional/Technical Component)

Sumber : Warsito Utomo, 1997

Dari gambar 2.1 tersebut menjelaskan bahwa dalam melihat tinggi rendahnya kualitas pelayanan publik perlu diperhatikan adanya keseimbangan antara : 
1. Bagian antar pribadi yang melaksanakan (Inter Personal Component) dalam hal ini adalah aparat pelaksana kegiatan pelayanan.

2. Bagian proses dan lingkungan yang mempengaruhi (Process and Environment Component) dalam hal ini adalah iklim organisasi.

3. Bagian profesional dan teknik yang dipergunakan (Professional and Technical Component) dalam hal ini system pelayanan.

Jadi dapat disimpulkan bahwa kualitas pelayanan publik dipengaruhi oleh aparat pelaksana kegiatan pelayanan, iklim organisasi dan sistem pelayanan.

\subsection{Kemampuan Aparat Pelaksana Kegiatan Pelayanan}

Usaha peningkatan kinerja pelayanan publik tanpa mengikut sertakan aparaturnya akan tidak berhasil. Selaku tenaga operasionalisasi dari suatu bentuk pelayanan umum, baik buruknya pelayanan umum tadi sangat tergantung pada penampilan aparaturnya, di samping faktor lainnya, seperti kinerja peraturan dan program kerjanya.

Siapa yang disebut aparatur pemerintah, adalah kumpulan manusia yang mengabdi pada kepentingan negara dan pemerintahan dan berkedudukan sebagai pegawai negeri (Thoha, 1996), sedangkan menurut Moerdiono (1992) mengatakan aparatur pemerintah adalah seluruh jajaran pelaksana pemerintah yang memperoleh kewenangannya berdasarkan pendelegasian dari Presiden Republik Indonesia.

Dengan kata lain aparatur negara atau aparatur adalah para pelaksana kegiatan dan proses penyelenggaraan pemerintahan negara, baik yang bekerja di dalam tiga badan eksekutif, legislatif dan yudikatif maupun mereka yang sebagai TNI dan pegawai negeri sipil pusat dan daerah yang ditetapkan dengan peraturan peraturan pemerintah.

Berkaitan dalam hal kualitas pelayanan publik, maka kemampuan aparat sangat berperan penting dalam hal ikut menentukan kualitas pelayanan publik tersebut. Jadi dapat disimpulkan yang dimaksud Kemampuan Aparat Pelaksana Kegiatan Pelayanan adalah kemampuan pelaksana kegiatan dan proses penyelenggaraan pemerintahan negara untuk melaksanakan tugas dalam rangka memperlancar tujuan organisasi. Untuk itu indikator-indikator dalam kemampuan aparat adalah sebagai berukut :

1. Tingkat pendidikan aparat;

2. Kemampuan penyelesaian pekerjaan sesuai jadwal;

3. Kemampuan melakukan kerja sama;

4. Kemampuan menyesuaikan diri terhadap perubahan yang dialami organisasi;

5. Kemampuan dalam menyusun rencana kegiatan;

6. Kecepatan dalam melaksanakan tugas;

7. Tingkat kreativitas mencari tata kerja yang terbaik;

8. Tingkat kemampuan dalam memberikan pertanggungjawaban kepada atasan;

9. Tingkat keikutsertaan dalam pelatihan/kursus yang berhubungan dengan bidang tugasnya.

\subsection{Iklim Organisasi}

Iklim organisasi menjadi sangat penting karena merupakan wadah setiap orang untuk menjalankan aktifitasnya. Tidak bisa dipungkiri bahwa manusia modern menjadi anggota berbagai organisasi yang kesemuanya dimaksudkan untuk mempermudah pencapaian tujuan, kepentingan dan kebutuhan pribadinya yang semakin lama semakin kompleks, terutama kebutuhan fisik. Dalam usaha pemenuhan kebutuhan yang bersifat fisik, manusia mencari nafkah melalui usaha menjadi karyawan dalam sesuatu organisasi tertentu, baik dilingkungan pemerintahan maupun dikalangan swasta.

Iklim organisasi merupakan istilah untuk menggambarkan lingkungan organisasi atau situasi organisasi. Iklim organisasi berkenaan dengan rangkaian sifat yang dapat dipersepsi orang-orang dalam suatu organisasi atau unit-unit tertentu. Pembicaraan tentang iklim organisasi sebenarnya 
merupakan pembicaraan lingkungan kerja dan timbul terutama karena kegiatan organisasi yang dilakukan secara sadar atau tidak, yang dianggap kemudian mempengaruhi perilaku organisasi (Savas, 1982). Iklim dapat dipandang sebagai kepribadian organisasi yang dilihat anggotanya.

Salah satu penelitian yang dilakukan oleh Campbell et.al, (1973) mengenai dimensi dari iklim kerja merupakan satu temuan yang cukup baik. Dengan menggunakan analisis gugusan atas daftar isian yang unik, para peneliti mengidentifikasi sepuluh dimensi iklim pada organisasi secara keseluruhan yang meliputi :

1. Struktur tugas tingkat perincian metode yang dipakai untuk melaksanakan tugas oleh organisasi.

2. Hubungan imbalan hukuman dan tingkat batas pemberian imbalan tambahan seperti tambahan promosi dan kenaikan gaji didasarkan pada prestasi dan jasa dan tidak pada pertimbanganpertimbangan lain seperti senioritas, favoritisme, dan lain-lain.

3. Sentralisasi keputusan. Batas keputusan-keputusan penting dipusatkan pada manajemen atas.

4. Tekanan pada prestasi. Keinginan pihak pekerja organisasi untuk melaksanakan pekerjaan dengan baik dan memberikan sumbangan bagi sasaran karya organisasi.

5. Tekanan pada latihan dan pengembangan. Tingkat batas organisasi berusaha meningkatkan prestasi individu melalui kegiatan latihan dan pengembangan yang tepat.

6. Keamanan versus resiko. Tingkat batas tekanan dalam organisasi menimbulkan perasaan kurang aman dan kecemasan pada para anggotanya.

7. Keterbukaan versus ketertutupan. Tingkat batas orang-orang lebih suka berusaha menutupi kesalahan mereka dan menampilkan diri secara baik dari pada berkomunikasi secara bebas dan bekerja sama.

8. Status dan semangat. Perasaan umum diantara para individu bahwa organisasi merupakan tempat kerja yang baik.

9. Pengakuan dan umpan balik. Tingkat batas seorang individu mengetahui apa pendapat atasannya dan manajemen mengenai pekerjaan.

10. Kompetisi dan keluwesan organisasi secara umum. Tingkat batas organisasi mengetahui apa tujuannya dan mengejarnya secara luwes dan kreatif, termasuk juga batas organisasi mengantisipasi masalah, mengembangkan metode baru dan mengembangkan ketrampilan baru pada pekerja sebelum masalah menjadi gawat.

Secara umum, iklim organsiasi adalah kondisi dalam penyelenggaraan pemerintahaan termasuk susunan bagian-bagian yang mempunyai tugas dan fungsi, yang saling berhubungan serta mempunyai tanggung jawab dan wewenang dalam pemberian pelayanan publik. Membahas iklim organisasi sangat terasa bahwa cakupannya demikian luas dan begitu kompleks namun dalam kaitannya dengan kualitas pelayanan publik, penulis tetap membatasi perhatian pada beberapa indikator saja meliputi:

1. Adanya situasi kerja khsusnya berkaitan kejelasan tugas dan wewenang

2. Peraturan yang mengatur tentang kelancaran dan ketertiban dalam pemberian pelayanan,

3. Adanya motivasi dari atasan dan pemeliharaan hubungan antar pegawai.

Hanya dengan menciptakan iklim kerja yang baik maka harapan akan kinerja pelayanan yang baik pada Kantor Kecamatan Samarinda Seberang dapat diwujudkan.

\subsection{Sistem Pelayanan}

Secara definisi sistem adalah suatu jaringan yang berhubungan satu sama lain menurut skema atau pola yang bulat untuk menggerakkan suatu fungsi yang utama dalam suatu usaha atau urusan (Prajudi, 1992). Namun bisa juga diartikan sebagai suatu kebulatan dari keseluruhan yang kompleks teroganisisr, berupa suatu himpunan perpaduan hal-hal atau bagian-bagian yang membentuk suatu kebulatan dari keseluruhan yang utuh (Pamudji, 1981).

Untuk sistem pelayanan perlu diperhatikan apakah ada pedoman pelayanan, syarat pelayanan yang jelas, batas waktu, biaya atau tarif, prosedur, buku panduan, media informasi terpadu saling menghargai dari masing-masing unit terkait atau unit terkait dengan masyarakat yang membutuhkan pelayanan itu sendiri. 
Dengan demikian sistem pelayanan adalah kesatuan yang utuh dari suatu rangkaian pelayann yang saling terkait, bagian atau anak cabang dari suatu sistem pelayanan terganggu maka akan menganggu pula keseluruhan palayanan itu sendiri. Dalam hal ini apabila salah satu unsur pelayanan sepertinggi mahalnya biaya, kualitasnya rendah atau lamanya waktu pengurusan maka akan merusak citra pelayanan di suatu tempat.

Beradasarkan uraian diatas, maka dapat ditarik simpulan bahwa sistem pelayanan adalah rangkaian yang kait mengkait secara utuh yang membentuk kebulatan dalam memberikan pelayanan yang terbaik kepada masyarakat sesuai tujuan organisasi. Dalam penelitian ini maka indikatorindikator sistem pelayanan yang menetukan kualitas pelayanan publik adalah :

1. Kenyamanan dalam memperoleh pelayanan berkait dengan lokasi tempat pelayanan;

2. Kejelasan informasi tentang pelayanan yang diberikan;

3. Perlindungan terhadap dampak hasil pelayanan.

2.8. Pengaruh Kemampuan Aparat Pelaksana Kegiatan, Iklim Organisasi Dan Sistem Pelayanan Terhadap Kualitas Pelayanan

Kualitas pelayanan publik sangat dipengaruhi oleh faktor iklim organisasi, kemampuan aparat dan sistem pelayanan. Ketiga faktor ini saling berkaitan satu sama lain dan tidak dapat dipisahkan dalam ikut menentukan tinggi rendahnya dan baik buruknya suatu pelayanan yang diselenggarakan oleh pemerintah.

Kualitas pelayanan publik mempunyai indikator ketepatan prosedur pelayanan mudah: kejelasan dan kepastian, kedisiplinan petugas, kemampuan petugas, kecepatan pelayanan, kenyamanan lingkungan, keadilan pelayanan, keamanan lingkungan, keramahan petugas dan akurasi pelayanan bebas dari kesalahan. Hal tersebut sangat dipengaruhi oleh faktor iklim organisasi, kemampuan aparat dan sistem pelayanan.

Semakin baik faktor iklim organisasi, kemampuan aparat dan sistem pelayanan maka kualitas pelayanan publik akan semakin baik pula dan semakin dapat memuaskan masyarakat sebagai pengguna hasil pelayanan. Sehingga kualitas pelayanan publik yang berkualitas dapat tercapai.

Berdasarkan penjabaran tersebut maka dapat dibuat suatu kerangka konsep sebagaimana yang dapat dilihat pada gambar 2.2 sebagai berikut:

Gambar 2.2

Konsep Tentang Faktor-faktor Yang Mempengaruhi

Kualitas Pelayanan Publik



Sumber : Peneliti [2010] 


\section{Metodologi}

\subsection{Jenis penelitian}

Mengacu pada tujuan penulisan ini yakni untuk menggambarkan kualitas pelayanan pembuatan Kartu Tanda Penduduk (KTP) di Kantor Kecamatan Samarinda Seberang, maka metode yang digunakan dalam penelitian ini adalah metode penelitian deskriptif kualitatif.

\subsection{Fokus penelitian}

Penelitian ini di fokuskan pada:

1) Ketepatan waktu pelayanan yang berkaitan dengan waktu tunggu dan proses

2) Kemudahan dalam pengajuan permohonan dan kelengkapan administrasi

3) Akurasi pelayanan yang berkaitan dengan apakah pelayanan tersebut bebas dari kesalahan

4) Besarnya biaya pelayanan

\subsection{Pemilihan informan}

Berdasarkan uraian diatas, dapat disimpulkan bahwa dalam menentukan Informan, sebagai sumber data utama dipilih secara purposive atau bertujuan dan teknik snowball sampling sesuai dengan kebutuhan dan kemantapan peneliti dalam pengumpulan data.

\subsection{Analisis data}

Analisis data dengan menggunakan model interactive model of analysis dengan empat komponen, yaitu pengumpulan data, data reduksi (reduction data), data display dan concluding drawing, yaitu terdiri dari tahap penyisiran dan verifikasi (Milles dan Huberman, 1992).

\section{Hasil Penelitan}

\subsection{Lokasi Penelitian}

Kecamatan Samarinda Seberang merupakan salah satu dari 6 (enam) Kecamatan yang terdapat di Kota Samarinda yang mempunyai luas wilayah $2766 \mathrm{Ha}^{2}$. Terdapat 8 (delapan) kelurahan yaitu :

1. Kelurahan Mesjid ;

2. Kelurahan Baqa ;

3. Kelurahan Rapak Dalam ;

4. Kelurahan Sungai Keledang ;

5. Kelurahan Harapan Baru ;

6. Kelurahan Sengkotek ;

7. Kelurahan Simpang Tiga;

8. Kelurahan Tani Aman.

Menurut Data Monografi Kecamatan Samarinda Seberang tahun 2009, jumlah penduduk Kecamatan Samarinda Seberang adalah 83.837 jiwa yang terdiri dari penduduk laki-laki sebanyak 42.675 jiwa dan penduduk perempuan 41.243 jiwa. Dengan jumlah penduduk terbanyak terdapat di kelurahan Mesjid dimana jumlah total penduduk sebanyak 17.977 dengan rincian penduduk laki-laki 8.264 dan penduduk perempuan sebanyak 9.713 .

Tabel 4.1

Jumlah Warga Wajib KTP, Memiliki KTP dan Belum Memiliki KTP

Di Kecamatan Samarinda SeberangTahun 2009

\begin{tabular}{|l|l|l|c|c|}
\hline No & Kelurahan & Wajib KTP & $\begin{array}{c}\text { Memiliki } \\
\text { KTP }\end{array}$ & $\begin{array}{c}\text { Belum } \\
\text { Memiliki KTP }\end{array}$ \\
\hline
\end{tabular}




\begin{tabular}{|c|l|c|c|c|}
\hline 1 & Simpang Tiga & 6.916 & 6.598 & 318 \\
\hline 2 & Sengkotek & 5.466 & 5.344 & 122 \\
\hline 3 & Harapan Baru & 6.567 & 6.522 & 45 \\
\hdashline 4 & Tani Äman & 4.009 & 3.976 & 33 \\
\hline 5 & Sungai Keledang & 5.411 & 5.392 & 19 \\
\hline 6 & Baqa & 5.119 & 4.987 & 132 \\
\hline 7 & Rapak Dalam & 9.031 & 8.775 & 256 \\
\hline 8 & Mesjid & 10.106 & 9.546 & 560 \\
\hline \multicolumn{2}{|c|}{ Jumlah } & 52.625 & 51.140 & 1.485 \\
\hline
\end{tabular}

Sumber : Monografi Kecamatan Samarinda Seberang, 2009.

\subsection{Hasil dan pembahasan penelitian}

\subsubsection{Ketepatan waktu pelayanan}

Ketepatan waktu pelayanan yang berkaitan dengan waktu tunggu dan proses. Semakin cepat dan tepat waktu dalam proses pelayanan, maka akan membuat pengguna jasa semakin puas.

Pelaksanaan pelayanan publik yang sangat diharapkan oleh masyarakat sebagai konsumen yaitu penggunaan waktu penyelesaian yang cepat. Dengan semakin cepat pelayanan yang diberikan, maka tingkat kepuasan masyarakat sebagai konsumen akan tinggi.

Dalam kaitannya dengan indikator ketepatan waktu, khususnya dalam kualitas pelayanan pembuatan Kartu Tanda Penduduk (KTP) di Kantor Kecamatan Samarinda Seberang untuk menciptakan pelayanan yang berkualitas adalah melalui percepatan waktu tunggu pada setiap jenis pelayanandan kualitas pelayanan khususnya berkaitan dengan kepastian waktu.

Masyarakat Kecamatan Samarinda Seberang yang mayoritas sebagai swasta/buruh dikenal memiliki watak yang keras akan sangat kecewa apabila segala urusan tidak bisa terselesaikan secara tepat waktu. Bahkan banyak masyarakat yang menilai keterlambatan pelayanan sebagai bentuk penundaan pekerjaan yang dilakukan pegawai di Kantor Kecamatan Samarinda Seberang.

Masyarakat Kecamatan Samarinda Seberang yang merasa tidak puas dengan ketepatan waktu pelayanan di Kantor Kecamatan adalah masyarakat yang mengalami keterlambatan penyelesaian maksimal lebih dari 1 (satu) minggu dari daftar waktu penyelesaian pelayanan.Namun adanya keterlambatan dalam waktu penyelesaian terjadi karena adanya adanya perubahan prosedur pelayanan dan adaptasi penggunaan sistem SIAK On Line.

\subsubsection{Kemudahan Dalam Pengajuan Permohonan Dan Kelengkapan Administrasi}

Indikator berikutnya yang menentukan kualitas pelayanan publik adalah kemudahan dalam pengajuan permohonan dan kelengkapan administrasi yang menyangkut prosedur atau tata cara, tidak berbelit-belit, mudah dipahami dan dilaksanakan. Kelengkapan administrasi akan mempermudah dalam proses penyelesaian setiap urusan pelayanan dan diperoleh data yang benar.

Pihak Kantor Kecamatan Samarinda Seberang secara tegas mensyaratkan kelengkapan administrasi dalam pengajuan permohonan, tetapi hal ini justru sering menyulikan masyarakat yang masih kurang paham akan kelengkapan administrasi dalam pengajuan permohonan. 
Bahwa dalam pengajuan permohonan dan kelengkapan administrasi di Kantor Kecamatan Samarinda Seberang meskipun mensyaratkan adanya kelengkapan administrasi, namun hal ini tidak didukung dengan adanya petunjuk yang jelas dalam setiap formulir pengajuan permohonan.

Pada sisi lain, pihak Kantor Kecamatan Samarinda Seberang diketahui tidak singkronnya antara Kantor Kecamatan Samarinda Seberang dengan Kantor Catatan Sipil. Hal ini menunjukan lemahnya koordinasi diantra kedua instansi dan tidak adanya prosedur yang jelas dan tetap berkaitan dengan persyaratan administrasi.

Adapun sistem dan prosedur pelayanan KTP sebagai berikut:

1) Pemohon KTP (Masyarakat)
a. Membawa Surat Keterangan dari RT
b. Membawa KTP lama (Memperpanjang KTP)
c. Membawa Kartu Keluarga

2) Kelurahan
a. Pengisian formulir
b. Pemeriksaan formulir
c. Pemberian resi
d. Penyerahan hasil KK, KTP dan surat keterangan penduduk lalu diserahkan ke Kecamatan

3) Kecamatan
a. Pemeriksaan formulir
b. Proses pemasukan data
c. Penerbitan KK dan KTP
d. Penerbitan Laporan Kependudukan
e. Penyerahan hasil KTP, KK dan surat keterangan kelurahan

4) Kantor Catatan Sipil dan Kependudukan
a. Proses terima data dari kecamatan
b. Proses konsolidasi
c. Proses kirim data kekecamatan
d. Proses MSI (Manajemen Sistem Informsi)
e. Penerbitan Laporan Kependudukan

\subsubsection{Akurasi Pelayanan}

Pihak Kantor Kecamatan Samarinda Seberang, menyadari bahwa setiap kesalahan seperti salah cetak, ada yang salah ketik merupakan murni kesalahan petugas Kantor Kecamatan Samarinda Seberang. Selama kelengkapan formulir administrasinya telah diisi dengan benar dan pihaknya siap untuk memperbaiki setiap kesalahan.

Setiap manusia pastilah pernah berbuat kesalahan baik itu disengaja maupun tidak. Namun yang terpenting adalah komitmen untuk memperbaiki kesalahan sehingga perlu adanya standarisasi jumlah minimal kesalahan yang dilakukan oleh petugas. 
Faktor biaya pelayanan dianggap penting karena faktor ini paling rawan dan krusial sekali di mata banyak pihak. Terkait dengan pelayanan KTP tidak dipungut biaya. Hal berdasarkan Perturan Walikota Samarinda Nomor 31 Tahun 2006 tentang Pembebasan Biaya Pembuatan Kutipan Akta Kelahiran, Kartu Keluarga dan Kartu Tanda Penduduk untuk Masyarakat dalam Wilayah Kota Samarinda.

Namun masyarakat secara sukarela mengeluarkan sejumlah dana dengan alasan kemanusian.Meskipun pemberian sukarela atas dasar kemanusiaan, namun tidak menutup harapan bagi masyarakat dengan adanya pemberian tersebut maka proses pembuatan KTP akan berjalan lancar.

Pada dasarnya bahwa biaya pelayanan KTP adalah gratis. Namun masyarakat dengan alasan kemanusiaan ataupun harapan ingin cepata dalam pelayanan mengeluarkan sejumlah dana.

4.3. Faktor-Faktor Yang Mempengaruhi Kualitas Pelayanan

\subsubsection{Kemampuan aparatur}

Dalam melayani kebutuhan dari pengguna jasa maka kemampuan aparat yang bertugas dalam hal pelayanan menjadi sangat penting. Demikian juga halnya dengan kemampuan aparat di Kantor Kecamatan Samarinda Seberang. Hal penting yang menjadi faktor penting dari kemampuan aparat di Kantor Kecamatan Samarinda Seberang adalah tingkat pendidikan aparat. Apabila diperinci satupersatu, maka dapat dilihat dalam tabel 4.2 sebagai berikut :

Tabel 4.4. Tingkat Pendidikan Pegawai Di Kantor Kecamatan Samarinda Seberang

\begin{tabular}{|c|c|c|}
\hline No & Pendidikan & Jumlah (orang) \\
\hline 1 & Pasca Sarjana / S2 & 2 \\
\hline 2 & Sarjana / S1 & 8 \\
\hline 3 & SLTA / SMEA & 20 \\
\hline 4 & SLTP & 1 \\
\hline 5 & SD & 1 \\
\hline \multicolumn{2}{|c|}{ Jumlah } & $\mathbf{3 2}$ \\
\hline
\end{tabular}

Sumber: Data umum pegawai Kantor Kecamatan Samarinda Seberang, 2009

Dari komposisi tingkat pendidikan aparat seperti pada tabel 4.4, terlihat bahwa kemampuan aparat di Kantor Kecamatan Samarinda Seberang belum tergolong baik. Hal ini dibuktikan dengan tingkat pendidikan SLTA/SMEA masih mendominasi jumlah keseluruhan pegawai yang berjumlah 20 orang.

Hal ini diakui oleh Kasi Pemerintahan Kantor Kecamatan Samarinda Seberang yang mengungkapkan bahwa latar belakang pendidikan berpengaruh terhadap kualitas pelayanan yang diberikan pegawai terhadap masyarakat.

Meskipun ada pula yang memiliki tingkat pendidikan S1 atau S2 namun diakui oleh Sekertaris Camat Kantor Kecamatan Samarinda Seberang, latar belakang pendidikan ini masih belum sesuai dengan jabatan yang diemban.

Untuk itu diperlukan adanya peningkatan kemampuan dalam meningkatkan kualitas pelayanan publik misalnya dalam bentuk pelatihan. berikut pelatihan yang telah diikuti petugas Kantor Kecamatan Samarinda Seberang, yaitu:

Tabel 4.5. Pelatihan Yang Di Ikuti Pegawai Di Kantor Kecamatan Samarinda Seberang

\begin{tabular}{|l|l|l|}
\hline No & Pelatihan Yang Diikuti & Jumlah (orang)
\end{tabular}




\begin{tabular}{|c|l|c|}
\hline 1 & Diklatpim II & 1 \\
\hline 2 & Diklatpim III & 3 \\
\hline 3 & Diklatpim IV & 6 \\
\hline 4 & Pelatihan Operator Komputer & 5 \\
\hline 5 & Pelatihan Kearsipan & 2 \\
\hline & Jumlah & $\mathbf{1 7}$ \\
\hline
\end{tabular}

Sumber: Data umum pegawai Kantor Kecamatan Samarinda Seberang, 2009

Adanya pelatihan ini memberikan pengaruh terhadap kualitas pelayanan yang diberikan petugas Kantor Kecamatan Samarinda Seberang. Dengan demikian bahwa pendidikan dan pelatihan memberikan pengaruh terhadap kualitas pelayanan KTP di KantorKecamatan Samarinda Seberang.

\subsubsection{Iklim Organisasi}

Melalui menciptakan iklim kerja yang baik maka harapan akan kinerja pelayanan yang baik pada Kantor Kecamatan Samarinda Seberang dapat diwujudkan. Untuk itu diperlukan adanya kemampuan melakukan kerja sama yang baik antar instansi dan di dalam instansi itu sendiri untuk meningkatkan kualitas pelayanan publik.Namun dalam pelaksanaan internal pelayanan KTP sering mengalami tumpang tindih. Meskipun tupoksi setiap pegawai sudah jelas akibat adanya masyarakat yang memberikan imbalan kepada petugas, padahal petugas yang bersangkutan tidak berhak melakukan pekerjaan tersebut.

Di setiap organisasi menuntut harus selalu mengevaluasi setiap hasil kegiatannya secara berkala, agar dapat diketahui perkembangan organisasinya tersebut, apakah organisasi tersebut perlu untuk dilanjutkan atau tidak.

Seperti halnya dalam penyusunan visi, misi dan sistem pemberian pelayanan dilakukan dengan melibatkan atasan dan bawahan sehingga membuat mereka merasa memiliki tanggung jawab sama dalam pemberian pelayanan kepada masyarakat pengguna jasa.

Juga perlu diadakan pertemuan rutin antar pegawai dan antar instansi terkait untuk saling memberikan masukan tentang kesulitan-kesulitan yang dialami dan keputusan yang dibuat menyalahi aturan organisasi. Dari sini bisa dipantau apakah perubahan dalam organisasi apakah menyimpang dari visi dan misi organisasi.

\subsubsection{Sistem pelayanan}

Dalam birokrasi yang meliputi serangkaian tindakan yang dilakukan aparat pelayanan yang merepresentasikan adanya pelayanan yang berdasarkan pada kemampuan aparat dalam memberikan pelayanan kepada masyarakat secara efisien dan tidak terlalu berdasarkan pada juklak dan juknis secara kaku.

Untuk itu dalam rangka memberikan kualitas pelayanan yang terbaik maka Kantor Kecamatan Samarinda Seberang harus memperhatikan setiap tuntutan dari masyarakat sebagai pengguna jasa dari pelayanan publik yang diselenggarakan.

Kenyataan yang ada di Kantor Kecamatan Samarinda Seberang menunjukkan bahwa faktor kenyamanan khususnya dalam pemberian akses informasi bagi masyarakat kurang diperhatikan. Hal ini terlihat dari bingungnya masyarakat dalam mencari informasi.

Dari kesemua uraian pada bab ini, jelas menunjukkan bahwa kualitas pelayanan publik di Kantor Kecamatan Samarinda Seberang masih perlu diperbaiki dan ditingkatkan lagi. 


\section{Simpulan}

Berdasarkan uraian pada poin 4 diatas dapat diambil beberapa kesimpulan sebagai berikut :

1) Kualitas pelayanan, hal ini disebabkan antara lain :

a. Masih banyak dari masyarakat yang mengeluhkan tentang ketepatan waktu pelayanan yang berkaitan dengan waktu tunggu dan proses yang dilaksanakan di Kantor Kecamatan Samarinda Seberang. Adanya keterlambatan dalam waktu penyelesaian terjadi karena adanya perubahan prosedur pelayanan dan adaptasi penggunaan sistem SIAK On Line

b. Dalam hal menetapkan persyaratan administrasi, Kantor Kecamatan Samarinda Seberang secara tegas mensyaratkan kelengkapan administrasi dalam pengajuan permohonan. Namun adanya keterlambatan karena tidak singkronnya antara Kantor Kecamatan Samarinda Seberang dengan Kantor Catatan Sipil. Hal ini menunjukan lemahnya koordinasi diantra kedua instansi dan tidak adanya prosedur yang jelas dan tetap berkaitan dengan persyaratan administrasi.

c. Biaya pelayanan KTP gratis namun ada beberapa masyarakat yang mengelurakan sejumlah dana dengan alasan kemanusiaan atauapun harapan agar proses pelayanan dipercepat.

2) Kemampuan aparat di Kantor Kecamatan Samarinda Seberangdinilai belum memenuhi harapan, disebabkan karena masih mendominasinya pegawai yang memiliki tingkat pendidikan SLTA/SMEA dan ketidaksesuaian antara latar belakang dengan jabatan yang diemban.

3) Iklim organisasi di Kantor Kecamatan Samarinda Seberang kurang mendukung karena masih adanya pekerjaan yang mengalami tumpang tindih diakibatkan adanya pemberian sejumlah dana kepada petugas untuk melaksanakan pekerjaan yang tidak sesuai tupoksinya dan adanya perintah dari Camat untuk melakukan pekerjaan tertentu.

4) Dalam hal sistem pelayanan di Kantor Kecamatan Samarinda Seberangterkait faktor kenyamanan khususnya dalam pemberian akses informasi bagi masyarakat kurang diperhatikan dikarenakan tidaka jelasnya akses informasi masyarakat terhadap sistem pelayanan.

\section{Daftar pustaka}

Arikunto, Suharsimi. 2006. Prosedur Penelitian Suatu Pendekatan Praktik, Rineka Cipta, Jakarta.

Barata, A.A .2003. Dasar-dasar pelayanan prima, Gramedia, Jakarta.

Boediono, 2003, Pelayanan Prima Perpajakan, PT Rineka Cipta, Jakarta

Campbel, J, R., Dunnettee, M. D., Lawler, E, E, III, and Weiek, K, E, Jr, (1973), Managerial Behaviour, Performance and Effektiveness, McGrew-Hill, New York

Dwiyanto, Agus, 2002, Reformasi Birokrasi Publik di Indonesia, Pusat Studi Kependudukan dan Kebijakan, UGM

Hadiningrat, Soewarno, 1983, Administrasi Pemerintahan Dalam Pembangunan Nasional. Gunung Agung, Jakarta.

Hatry, H.P, 1989, "Determining the effectiveness of Government Services", in James L. Perry (ed), Handbook of Public Administration, CA Jossey-Bass Publishers, Sanfrancisco.

Hausser, D. L., Pecorella. P.A \&Wissler, A.L. 1977, Survey-Guided Development: A Manual For Consultants, CA, University Associates, San Diego.

Keputusan Menteri Pendayagunaan Aparatur Negara Nomor 81 Tahun 1993 Tentang Pedoman Tatalaksana Pelayanan Umum, Penerbit. : MENPAN

Lawler, E.E Hall, D. T. and Oldhum, G.R, (1974) Organtional Climate: Relationship to Organizational Strucktur, Processes and Performance. Organizational Behaviore and Human Performace 11, 139-155

Lembaga Adminsitrasi Negara, 2003 "Penyusunan Standar Pelayanan Minimum"

Lovelock, Christoper 1994 Product Plus :How Product Service Competitive Advantge. Mc Graw Hill, New York. 
Milles dan Huberman, 1992. Analisa Data Kualitatif. Ghalia Indonesia, Jakarta.

Moenir, 1992, Manajemen Pelayanan Umum di Indonesia, Bumi Aksara, Jakarta

Moerdiono, 1992, Birokrasi dan Administrasi Pembangunan : Beberapa Pemikiran Pemecahan, Sinar Grafika, Jakarta.

Moleong, Lexy. 2000. Metode Penelitian Kualitatif, Rema Posdakarya, Bandung.

Nasution. 1992Metode Penelitian Naturalistik Kualitatif. Tarsito, Bandung.

Nawawi, Hardadi. 1999. Metode Penelitian Bidang Sosial, Gajah Mada Press, Yogyakarta.

Pamudji, S., 1981. Demokrasi Pancasila dan Ketahanan Nasional. Bina Aksara, Jakarta

Payne, R, L and Pheysey, D.C (1971). G.G. Stern's Organizational Climate Indekx: A Reconceptualisation and Application to Business Organization, Journal Organization Behaviore and Performace, Volume 6: 77-98.

Pembukaan Undang-Undang Dasar 1945, PT. Pradnya Paramita, Jakarta

Pemerintah Kota Samarinda, 2009, Ayo, Tingkatkan Pelayanan Publik. Materi diakses di www.samarinda.co.id, diakses tanggal 2 Oktober 2009.

Prajudi. 1992. Administrasi dan Management Umum PT Raja Grafindo Persada. Admosudirdjo, Ghalia Indonesia, Jakarta.

Robbins, S.P., 1995, Managing Organizational Conflict : A Non-Traditional Approach, NJ: Prentice Hall, Englewood Cliffs

Savas, Es 1982 How To Shrink Government Privatizing The Public Sector. Chatam House Publisher, New Jersey.

Sekretariat Daerah Kota Samarinda, Peraturan Pemerintah Nomor 19 Tahun 2008 Tentang Kecamatan

,Peraturan Walikota Samarinda Nomor 31 Tahun 2006 Tentang Pembebasan Biaya Pembuatan Kutipan Akta Kelahiran, Kartu Keluarga dan Kartu Tanda Penduduk (KTP)

Sjahrir, 1987, Kebijaksanaan Negara: Konsistensi dan Implementasi, Jakarta, LP3ES.

Soesilo Zauhar, 2001, Adminstrasi Pelayanan Publik Sebuah Perbincangan Awal, Jurnal Administrasi Negara VoI. 1, No. 2, Maret 2001 Universitas Sam Ratulangi

Soetopo, 1999, Pelayanan Prima, LAN RI, Jakarta.

Sugiyono, 1998, Metode Penelitian Administratif, Rineka Cipta, Jakarta.

Thoha, Miftah, 1996, Deregulasi dan Debirokratisasi dalam Upaya Peningkatan Mutu Pelayanan Masyarakat : dalam Pembangunan Administrasi di Indonesia, LP3ES, Jakarta.

Tulus. Moh, Agus, 1992, Manajemen Sumber Daya Manusia, Gramedia Pustaka Utama, Jakarta.

Undang-Undang Nomor 22 Tahun 1999 Tentang Pemerintahan Daerah, SEKRETARIAT KABINET RI. Kepala Biro Peraturan. Perundang-undangan II

Undang-Undang Nomor 32 Tahun 2004 Tentang Pemerintahan Daerah. SEKRETARIAT KABINET RI. Kepala Biro Peraturan. Perundang-undangan II

Utomo, Warsito, 1997, Peranan dan Strategi Peningkatan Pendapatan Asli Daerah (PAD) dalam Pelaksanaan Otonomi Daerah, dalam Jurnal Ilmu Sosial dan Ilmu Politik, volume 1.

Widodo, Joko, 2001, Good Governance : Telaah dari Dimensi Akuntabilitas dan Kontrol Birokrasi Pada Era Desentralisasi dan Otonomi Daerah, Insan Cendekia, Surabaya

Zeithaml, Valarie A., (et.al), 1990, Delivering Quality Services : Balancing Customer Perceptions and Expectations, The Free Press, A Division of Macmillan Inc., New York. 